\title{
A Study on the Intercontinental Transportation Competitiveness Enhancement Plan between Northeast Asia and Europe Using the Trans-Siberian Railway
}

\author{
Ji-Young Song and Hee-Seung $\mathrm{Na}$
}

\begin{abstract}
According to the extension and growth of the Northeast Asian economic bloc, the transfer of logistics between Northeast Asian countries and European countries has enlarged and the major countries of Northeast Asia have played a central role in the Northeast Asia economic bloc as logistics hubs. Currently, due to an increase in international freight volume, international shipping and air freight continues to increase. Due to lack of infrastructure and increase of transportation costs however, Northeast Asia's logistics competitiveness has weakened. It is therefore necessary to develop more efficient and reliable international transportation network. By analyzing the current status of major transportation paths between Northeast Asia and Europe currently in operation and their technical characteristics, this paper suggests an improvement plan for more efficient transportation and a transportation competitiveness enhancement plan, to solve realistic problems such as economic transportation technology and uncertainty of demand, and enhance the possibility of transportation costs and time savings. However, a result of comparative analysis of marine transportation and transcontinental railway shows that transcontinental railway competitiveness has decreased sharply. To enhance this, it necessary to invest and build mutual cooperation between countries, form a global network and create a mutual compensation system for an international transportation complex.
\end{abstract}

Index Terms-Northeast asian economy, logistics competitiveness, trans-siberian railway, natural resource

\section{INTRODUCTION}

As the entry of Northeast Asia into Europe increases, relevant countries are seeking new traffic corridor alternatives to connect Korea, China and Japan to Europe.

The Northeast Asian countries optionally operate these transportation line alternatives through shipping, railways, roads, shipping-railway connections, shipping-road connections, shipping-road-railway connections, and others. They also use a variety of lines like the Suez Canal, TCR, TSR, TMR, TMGR, High speed freight railway and more, , and a variety of clearances such as block trains, bilateral, transit, custom freight, and the like.

Considering the transportation demands of the future, railway freight transportation is becoming more important as investment in land transportation by rail supports railway freight transportation. By analyzing the current status of

Manuscript received February 12, 2012; revised March 28, 2012.

Jiyoung Song is with the University of Science and Technology, Department Transportation and Logistics system, Uiwang City, Republic of Korea (e-mail: jysong@krri.re.kr).

Hee-Seung $\mathrm{Na}$ is with the Korea Railroad Research Institute, Department of planning, Uiwang City, Republic of Korea (e-mail: hsna@krri.re.kr). major transportation paths between Northeast Asia and Europe currently in operation and their technical characteristics, this paper suggests an improvement plan for more efficient transportation and a transportation competitiveness enhancement plan.

In conclusion, we tried to seek a Northeast Asia and Eurasian continent railway cooperation plan and an intercontinental railway transportation competitiveness enhancement plan by analyzing the realistic problems of each transcontinental transportation line from economic and social points of view.

\section{THE CURRENT NORTHEAST ASIA TRANSCONTINENTAL TRANSPORTATION STATUS}

The ports of Northeast Asia cover over $40 \%$ of the container throughput of all ports in the world, and have continued to increase since 1980. The position of Northeast Asia has grown stronger in international logistics transportation.

The Economic and Social Council of the UN has promoted the simplification of border passage procedures for Asian railways and highways as a part of the Asia Land Transport Infrastructure Development Project. The Asian Railway Project which this paper is focused on, aims at the economic development and traffic system integration of Northeast Asia through economic connections between Northeast Asia and Europe, and includes the application of existing lines through connecting missing links, constructing new railway lines, preferred connection projects in demanding areas, increase of complex transportation efficiency by major ports and railways, operation of container block trains, and other measures. There are two transportation methods between Northeast Asia and Europe: marine transportation by ship and transcontinental railway transportation by railway. The major inland transportation lines include the Trans-Siberian Railway (TSR) connecting each area of Europe from Vostochny port, and the Trans-China Railway (TCR) which starts from Lianyun port and connects Europe via Kazakhstan and Russia.

\section{A. The current Status of Major Transportation Lines between Northeast Asia and Europe}

\section{1) Overview of marine transportation and Northeast Asian} transcontinental transportation

The most general logistics transportation path between Northeast Asia and Europe is the marine transportation path. More than $98 \%$ of container liners that currently connects major ports between Far Eastern Asia and Europe use the 
Suez Canal to transport freight [1]. The path through the Suez Canal is the most common transportation route, reaching about $21,978 \mathrm{~km}$ and most shipping companies in the far-east who participate in trade with Europe stop at Busan port. It takes an average of 28-35 days to transport containers to the major ports of Europe using the Suez Canal (Ko Seungwoo, "Study on the effect that TKR and TSR connection gives the international transportation logistics market of Korea", Korea Maritime University, 2005.2). When we look at the major base ports where shipping companies operating this path stop, Europe has Rotterdam in Netherlands, Hamburg in Germany, Felixstowe in the UK, and Antwerp in Belgium. Asia has Singapore, Hong Kong, Kaohsiung in Taiwan, Busan in Korea, and Kobe and Tokyo ports in Japan.

Of these, the marine transportation route operating from Busan to Finland takes an average of 30 35 days. Compared with this, the line connecting Finland through Fareast ports and the Trans-Siberian Railway (TSR) takes about 25 days, reducing the transportation period.

TABLE I : COMPARISON OF TRANSPORTATION DAYS AND FREIGHT CHARGES BETWEEN SHIPPING-CENTERED TRANSPORTATION AND RAILWAY-SHIPPING TRANSPORTATION.

\begin{tabular}{llll}
\hline \multicolumn{3}{c}{ RAILWAY-SHIPPING TRANSPORTATION. } & \\
\hline Classification & Section & $\begin{array}{l}\text { Transp-ortation } \\
\text { days }\end{array}$ & $\begin{array}{l}\text { Freight } \\
\text { charge } \\
\text { (20TEU) }\end{array}$ \\
\hline Shipping-centered & $\begin{array}{l}\text { Capital area-Busan } \\
\text { port-Suez } \\
\text { Canal-Rotterdam-Brest } \\
\text { Capital area-Busan } \\
\text { port-Vostochny-Brest } \\
\text { Capital area-Busan } \\
\text { port-Lianyun } \\
\text { port-Brest }\end{array}$ & $28-30$ & $\$ 2,280$ \\
\hline \hline & Reconstructed based on data of Korea Maritime Institute
\end{tabular}

TABLE II: MAJOR TRANSCONTINENTAL RAILWAY LINE SPECIFICATIONS

\begin{tabular}{|c|c|c|c|c|c|}
\hline Classifi- cation & Section & $\begin{array}{l}\text { Dista-Double } \\
\text { nce track }\end{array}$ & $\begin{array}{l}\text { Rail- road } \\
\text { Electri- } \\
\text { fication }\end{array}$ & Track gauge & Remarks \\
\hline $\begin{array}{l}\text { Trans-China Railway } \\
\text { (TCR) }\end{array}$ & $\begin{array}{l}\text { Lianyun port } \sim \text { Jeongju } \sim \text { LanZhou } \sim \text { Urumqi } ~ \\
\text { Arasanku }(\mathrm{Cn}) \sim \text { Druzhba }(\mathrm{Ka}) \sim \text { Presgonorkovka } \\
(\mathrm{Ka}) \sim \text { Zaulalie St. }(\mathrm{Ru}) \text { connecting to TSR }\end{array}$ & $8,6137,127$ & 5,001 & $\begin{array}{l}\text { China standard gauge } \\
(1,435 \mathrm{~mm}) / \text { Kazakhstan } \\
\text { broad gauge }(1,520 \mathrm{~mm})\end{array}$ & - Freight system: ETT \\
\hline $\begin{array}{l}\text { Trans-Manchuria } \\
\text { Railway (TMR) }\end{array}$ & $\begin{array}{l}\text { Domun } \sim \text { Manchuri }(\mathrm{Cn}) \sim \text { Zabaykalsk }(\mathrm{Ru}) \sim \\
\text { Kalimskaya St. }(\mathrm{Ru}) \text { connecting to TSR }\end{array}$ & $7,7217,367$ & 6,067 & $\begin{array}{l}\text { China standard gauge } \\
(1,435 \mathrm{~mm})\end{array}$ & \\
\hline $\begin{array}{l}\text { Trans-Mogolian } \\
\text { Railway (TMGR) }\end{array}$ & $\begin{array}{l}\text { Tienjin }(\mathrm{Cn}) \sim \text { Beijing } \sim * \text { Eren Hot }(\mathrm{Cn}) \text { - Zamiin } \\
\text { Uud }(\mathrm{Mo}) \text { - Ulaanbaatar } \sim \text { Suhbator }(\mathrm{Mo}) \text { - Nauski } \\
(\mathrm{Ru}) \sim \text { Ulan Ude St. }(\mathrm{Ru}) \text { connecting to TSR }\end{array}$ & $7,7536,296$ & 5,777 & $\begin{array}{l}\text { Mongolia broad gauge } \\
(1,520 \mathrm{~mm})\end{array}$ & $\begin{array}{l}\text { Single track railway for the } \\
\text { whole section of Mongolia }\end{array}$ \\
\hline
\end{tabular}

Reconstructed based on data of Korea Railroad Research Institute

With the collapse of the USSR in the 1990's, the Russian economy was shaken, and the TSR was depressed for a decade. Korea made a great effort to use the Russian transportation market, based on the reliability of the railroad, and a push for business in Russia. The transportation demand for mass construction materials and production parts with the start of local production, followed by the entry of electric home appliances and cars into the Russian market, encouraged maximized the use of the TSR.
For marine transportation, due to the recent input of large scale ships of over $6,000 \mathrm{TEU}$ to provide service at low price, it is not hard to see the superiority of marine transportation over railway transportation. [1]

\section{2) Various Northeast Asia transcontinental transportation lines}

There are 4 major transcontinental railway lines between Northeast Asia and Europe including TSR, TCR, TMR and TMGR. The characteristics of these lines are listed in Table II below.

The TSR was designed in 1850for the purpose of increasing military presence in the far-east, colonization, and trade with China. The scheduled line was planned for construction along the Siberian Road. It was researched in 1887, constructed between 1891 and 1892, and partially opened in 1897. It is the longest direct train running $9334 \mathrm{~km}$. The electrification of the railroad began in 1929 and was completed for all sections in 2002. [2]

The TSR, as a subject of freight transportation passage for Europe, enabled the former Soviet Union to obtain foreign currency and currently takes charge of transportation for Russian and CIS countries, playing an important role connecting Europe and Asia.

The TSR international container transportation established a system transporting faster than the Suez Canal, which depends on a combination of railway and shipping through the international combined transport system developed in the 1970's. 
total length in China is $4,128 \mathrm{~km}$ and most of the line has double tracking and electrification completed, using standard gauge (track gauge: $143.5 \mathrm{~cm}$ ). It uses the automatic closed method as the signal system for the entire line.

\section{COMPARATIVE ANALYSIS OF COMPETITIVENESS BETWEEN THE TRANSCONTINENTAL RAILWAYS OF NORTHEAST ASIA PREPARE}

\section{A. Comparison of Competitiveness between the Transcontinental Railways of Northeast Asia}

It was determined that the TSR's competitiveness includes its shorter distance than marine transportation, low costs versus transport time, the future possibility of connection with the Trans-Korea Railway (TKR) and Trans-Asia Railway (TAR), the possibility of market development around Russia, et cetera.[3] The TSR is making efforts to secure punctuality through on-time freight train management with the introduction of GPS to expand its transportation service. In addition, it promotes technical improvements by engaging high speed freight trains. It has some problems however, including low service quality, incomplete line connections, higher transportation costs than ocean freight, low service frequency, problems of collecting empty containers vis a vis unbalanced western freight and others.[4] To increase TSR competitiveness in the future, transport time and service which are properties that the shipper is sensitive to must be improved upon. To achieve this, clearance, border passage, and required freight train change times must be minimized, as they are the main causes of delay. To improve transportation capacity, securement of sufficient freight train inventory is urgently needed. As the TSR freight is weighed in western ports, empty containers in eastern must be returned quickly, and at low cost.

TABLE III: COMPARISON OF MAJOR LINES BETWEEN BUSAN AND BERLIN

\begin{tabular}{llll}
\hline Line & $\begin{array}{l}\text { Distance } \\
(\mathrm{km})\end{array}$ & $\begin{array}{l}\text { Cost } \\
(20 \mathrm{TEU})\end{array}$ & $\begin{array}{l}\text { Transporta-ti } \\
\text { on time }\end{array}$ \\
\hline $\begin{array}{l}\text { Busan-Vostochny-Brest- } \\
\text { Hamburg-Berlin }\end{array}$ & 12,047 & $\$ 1,285$ & 18 days \\
$\begin{array}{l}\text { Busan-Lianyun } \\
\text { port-Brest-Hamburg-Berlin }\end{array}$ & 12,248 & $\$ 2,459$ & 26 days \\
$\begin{array}{l}\text { Busan-Hamburg-Berlin } \\
\text { (Shipping via the Suez }\end{array}$ & 19,500 & $\$ 2,290$ & 35 days \\
\begin{tabular}{l} 
Canal) \\
\hline \hline
\end{tabular}
\end{tabular}

Reconstructed based on an analysis of the russian railroad mnistry

The Trans-China Railway (TCR) can shorten the railroad operation distance between Northeast Asia and Europe. Compared to the TSR, it is about $1,000 \mathrm{~km}$ shorter which should reduce transportation time. This shorten the distance in freight transportation between Northeast Asia and Central Asia and permits combined transportation using the ports of China which are leaders in different kinds of freight transportation.
TABLE IV: REGULAR OPERATION BLOCK TRAIN OF TRANS-SIBERIAN RAILROAD

\begin{tabular}{|c|c|c|c|c|c|}
\hline Destination & Departure & $\begin{array}{l}\text { No. } \\
\text { of } \\
\text { trains } \\
\text { /week }\end{array}$ & $\begin{array}{l}\text { Requi-red } \\
\text { days }\end{array}$ & Operator & $\begin{array}{l}\text { Major } \\
\text { Shipper }\end{array}$ \\
\hline Taganlog & Vostochny & 3 & 11 & $\begin{array}{l}\text { Russkaya } \\
\text { Troikasa }\end{array}$ & $\begin{array}{l}\text { HYUNDAI } \\
\text { Motors/ } \\
\text { TahAZ } \\
\text { KIA }\end{array}$ \\
\hline Izefsk & Vostochny & $7 \sim 8$ & 9 & $\begin{array}{l}\text { Russkaya } \\
\text { Troikasa }\end{array}$ & $\begin{array}{l}\text { Motors/ } \\
\text { JSC, } \\
\text { Izhavto }\end{array}$ \\
\hline Moscow & Vostochny & 1 & $11 \sim 12$ & $\begin{array}{l}\text { Russkaya } \\
\text { Troikasa } \\
\text { F.E. } \\
\text { Trans Co. } \\
\text { Trans }\end{array}$ & \\
\hline $\begin{array}{l}\text { Saragachi } \\
\text { (Uzbekistan) }\end{array}$ & Vostochny & 2 & 14 & $\begin{array}{l}\text { Container } \\
\text { Co., } \\
\text { Unico } \\
\text { Logistics }\end{array}$ & $\begin{array}{l}\text { GM- } \\
\text { Daewoo }\end{array}$ \\
\hline Navereznuy & Vostochny & 3 & $9 \sim 10$ & $\begin{array}{l}\text { F.E. } \\
\text { Trans Co. }\end{array}$ & $\begin{array}{l}\text { SSANG- } \\
\text { YONG } \\
\text { Motors/ } \\
\text { JSC }\end{array}$ \\
\hline
\end{tabular}

If connection to Europe becomes possible however, as it passes through Kazakhstan -Russia border, the freight charge for each section may become excessively high, including inefficiencies in clearance and quarantine, container transshipment capacity and warehouse conditions, which are not suitable for international freight transportation.

\section{TRANSPORTATION COMPETITIVENESS ENHANCEMENT PLAN AND OPTIMAL TRANSPORTATION CONDITIONS}

\section{A. TSR Transportation Competitiveness Enhancement Plan}

The TSR freight volume is seriously affected by alternative route prices and the rise in ocean freight charges has a positive effect on the TSR. Generally, container ship charges hit bottom in January, 2002 and reached a peak in April, 2005. Since then, it dropped out in 2006 and began to rise again at the end of the same year. For container ship to Europe, the charge was $\$ 1800 / 20$ until autumn of 2005 and crashed to $\$ 1400 / 20$ in the spring of 2006 . This happened because of the increase in ship supply of large foreign shipping companies. Due to an upswing in freight moving to Europe, ocean freight charge began to rise again. A wide change in container ships like this, affected the competing TSR's freight. However, there is the problem that when determining the rise in TSR freight charge, international trends in competing marine transportation routes were not completely considered. Preparation and reaction of a detailed fare policy after identifying the competitor is required. [7]

Regarding the recent rise in TSR freight charge, when we give passage freight for Finland as an example, we can read the pattern when they announce a small cut after a steep rise. Shippers who suffered from repeated increases established a system to change to alternative routes at any time. In addition, several Engines which transport large freight are also making great efforts to reduce maximum risk with long-term contracts. A one-sided policy such as repeated increases in 
freight charge by TSR, separation of management, etc., should be diversified into the management efficiency investment fund supply, and more. [6]

Currently, besides a lack of objective handling capacity due to backward port logistics facilities in the far-east, complicated ownership structures and inefficient port operations cause delays in loading/unloading. Accordingly, organic cooperation between marine ports and railroads for the development of international transportation is needed. Currently far-east ports do not satisfy the requirements for a combined transportation system. Active efforts by the port companies in loading and unloading are required, together with a competitive railroad freight system.

The TSR transportation route was born in 1970's and revived in the $21 \mathrm{st}$ century by adapting to a changing economic environment during the collapse of the Soviet Union. Korea made great efforts to use the TSR as a path of trade to Russia, but Russia changed its policy, substantially abolishing cheap international passage freight charges. It is thus urgent to establish a plan to increase competitiveness as they still have difficulties to solve, such as technical problems with transportation capability, clearance problems, and others. To address the perception that the TSR is expensive, a flexible response is possible if it associates with marine logistics in a transportation project which regularly handles mass freight. In addition, the activation of an international cooperation system by the introduction of competitiveness is expected. The connection plan between the TSR and TKR needs a promotion strategy together with revitalization of a combined transportation network on the East Sea rim. A win-win strategy for mutual benefit through enhancement of the East Sea rim combined port and railway transportation network with neighboring countries is needed. Efforts to initiate a Northeast Asia logistics hub city development consulting group to connect major port cities and railroad base cities of Northeast Asia will help in the mid- and long term.

\section{B. Securing Natural Resource Competitiveness in Central Asia and Connection with Northeast Asia}

The Russian oil and natural gas markets have become the driving force for economic growth in Russia, which is promoting a policy to secure reliability and investment from the international community. Russia has the richest sources of crude oil, natural gas, and coal in the world.

Russia established the "Russia Federal Energy Strategy-2030" at the end of 2009, and announced new energy policy goals taking into account the economic crisis in Russia. This is a strategy to maximize the efficiency of potential energy to achieve sustainable economic growth, improve Russian quality of life and enhance Russia's position in foreign economic relations. By adding innovative development to the content mentioned in the "Russia Federal Long-term Social Economic Development Program-2020" announced in 2008, it intends to develop its energy field. The contents include energy security and improvement of national competitiveness, reorganization of industrial structure to reduce energy dependence, development and modernization of the fuel energy industry, increase in investment to expand the business scope, improvement of energy efficiency, reduction of the economy's energy weight, reduction of environmental and climate effects by reducing the discharge of waste generated from energy production and consumption, and more. [5]

As most areas are still under exploration, there are many choices in which businesses can participate. In particular, the Caspian Sea region is estimated to have about 203.2 billion barrels of cruel oil and 1585 trillion $\mathrm{m}^{2}$ of natural gas reserves.

Kazakhstan is evaluated higher than other Central Asian countries in size and numbers of oil reserves.

TABLE V: OIL RESERVES OF MAJOR EURASIAN COUNTRIES

\begin{tabular}{ll}
\hline \hline Country & Identified deposits (100 million barrel) \\
\hline Russian Federation & $790($ world $6.3 \%)$ \\
Azerbaijan & 70 \\
Kazakhstan & $396($ world 3.3\%) \\
Turkmenistan & 5.5 \\
Uzbekistan & 13.4 \\
\hline \hline
\end{tabular}

The cruel oil reserves identified in Kazakhstan comprise 39.6 billion, covering $3.3 \%$ of worldwide share. But production per day is only 1.3 million barrels $(1.6 \%)$. This means that there are still many choices for development.

Export of oil by rail encompasses about $5 \%$ of all Russian oil exports, but if Russian pipeline network capacity is not extended, non-pipeline exports will increase for several years in the future. Railroad transportation is one of major methods by which Russia provides crude oil to East Asia, and despite the growth of China, Russia exports crude oil by rail to the center of China via the North-eastern cities such as Harbin and Daching, and Mongolia due to the absence of a pipeline. Export of crude oil to China by rail, according to the Chinese Ministry of Railways, increased from 200,000 bbl/d in 2005 to $300,000 \mathrm{bbl} / \mathrm{d}$ in 2006 .

The crude oil transportation capacity of Littoral Province ports reached an average of 1.5 million bbl/d in 2007 and is increasing. Due to the use of large reservoir tanks, port capacities continued to increase in 2009 and port export capabilities doubled (approximately 3 million bbl/d).

TABLE VI: GAS PRODUCTION AND ITS PERCENTAGE FOR MAJOR COUNTRIES OF CIS

\begin{tabular}{llllll}
\hline \hline & \multicolumn{2}{l}{ Deposits $\left(1\right.$ trillion $\left.\mathrm{m}^{3}\right)$} & \multicolumn{2}{c}{ Production $\left(100\right.$ million $\left.^{3}\right)$} \\
Country & \multicolumn{2}{l}{$\begin{array}{l}\text { Identified Potential Total } \\
\text { deposits }\end{array}$} & $\begin{array}{l}\text { deposits } \\
\text { estimated }\end{array}$ & $\begin{array}{l}\text { World production } \\
(2008)\end{array}$ \\
\hline Azerbaijan & 0.85 & 1.0 & 1.85 & 147 & $0.5 \%$ \\
Kazakhstan & 1.8 & 2.5 & 4.3 & 302 & $1.0 \%$ \\
Turkmenistan & 2.0 & 4.5 & 6.5 & 661 & $2.1 \%$ \\
Uzbekistan & 1.9 & 1.0 & 2.9 & 622 & $2.0 \%$ \\
\hline \hline
\end{tabular}

As a part of transcontinental railway demand creation, the countries directly involved can prepare a transportation policy for mutual benefit through resource trade in Russia and Central Asian countries. 


\section{CONCLUSIONS}

Transportation connecting Northeast Asia and Europe should consider the ripple effect in respect to logistics transportation and the economic ripple effect that countries directly involved will directly or indirectly have. This includes the possibility of reducing logistics costs and transportation time, the possibility of securing such resources as natural gas and oil, enlarging trade in the region, the possibility of forming a Northeast Asia economic bloc, and whether or not to promote revitalization of bilateral or multilateral economic cooperation. As emphasized above, the major issues of transcontinental transportation are summed up by 4 issues as follows.

Logistics movement to Europe can shorten transportation by as much as 10 days using rail rather than shipping. In addition, considering the profits of relevant countries through passage income, development of infrastructure and service like clearance simplification which eases logistics transportation, is the task of a transcontinental railway to solve. The reason for using a transcontinental railway is because resources such as natural gas and oil can be secured and trade in the region can be enlarged. As shown in 4.2, the energy resources and wood and fishery resources of Far-east Siberia and Central Asia can be a target of trade and investment between the countries directly involved, due to cost reduction through logistics environment improvement in Northeast Asian countries. The revitalization of trade in the region and increase of mutual investment shall promote the formation of the Northeast Asian economic region. In particular, transcontinental railway connection transportation via the TSR can bind Russia's far-east Siberian region, the Japanese Islands and the 3 provinces of East-northern China as one economic-logistics region. The differences in social and economic systems for each country may cause difficulty in economic integration, but improvement of the transcontinental railway environment will surely play a role in strengthening unity in the region.

In Northeast Asia, there is the nuclear issue of North Korea and problems between countries which have not improved international relationships since World War II. They remain bound by issues that cause tension. Ultimately however, as Northeast Asian countries, they should realize the optimal transportation benefits of the iron Silk Road by maximizing the strength of transcontinental lines which provide the 4 logistics advantages above.

\section{REFERENCES}

[1] Hyungin Jin, "Plan to build an international combined transportation network through the TAR application", Korea Maritime Institute, 1998

[2] Seungwoo Ko, "Study on the effects that TKR and TSR connection gives the international transportation logistics market of Korea", Ph.D. dissertation, Korea Maritime University, 2005

[3] Kwanghee Lee, "Study on the economic ripple effect of TKR-TSR connection", Ph.D. dissertation, Kyungwon University, 2007

[4] Kichan Nam, Juyoung Yoo, Taewon Kim, "Study on Trans-Siberian Railway competitiveness analysis", Ph.D. dissertation, Korea Maritime University,

[5] Jiyoung Song, Heeseung Na, "A Study on the strategy for securing the energy resources of the Korean Peninsula", presented at the Autumn Conf. the Korean Railway Society, Chang-Won, May 20-22, 2010,

[6] Jiyoung Song, "Study on Korean-Russian railway cooperation and transportation competitiveness enhancement plan", presented at the Autumn Conf. the Korean Railway Society, Jeju, October 21-23, 2010 ,

[7] Patrick S. McCarthy, Transportation economics, Blackwell publishers, 2001, pp 149-192

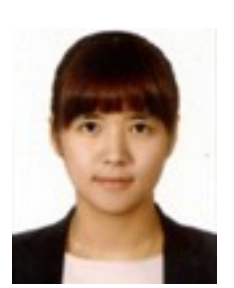

Ji-Young Song was born in the Seoul City on December $22^{\text {nd }}$ in 1984. She received BSc and MSc degree, in Transportation Economics from Siberia Transport University, Novosibirsk, Russia in 2008. She is currently doing her $\mathrm{PhD}$ from Transportation and Logistics Department in The University of Science and Technology, Republic of Korea. She is working as Researcher in the Transportation system research team of Korea Railroad Research Institute since 2008. Her research interests include Transportation Planning, Transportation Economics, Economical statistics and International rail network. Ms. Song is the member of The Korean Society for Railway (KSR) and World Academy of Science, Engineering and Technology (WASET)

Hee-Seung Na was born in Gwang Ju City on February $4^{\text {th }}$ in the year 1966. He received Ph.D. in Mechanical Engineering from Korea Advanced Institute of Science and Technology, Dae-Jeon, Republic of Korea in 1996. He is working as Senior Researcher in the New Transportation research team of Korea Railroad Research Institute. His current research interests include Transcontinental Railway system and New Transportation. 